\title{
STATUS TERUMBU KARANG DAN IKAN KARANG DI GILI MATRA, NUSA TENGGARA BARAT
}

\author{
Eghbert Elvan Ampou $^{1 *}$, Nuryani Widagti ${ }^{1)}$, Suciadi Catur Nugroho ${ }^{2)}$, \\ Ikram M. Sangadji ${ }^{3)}$ \\ ${ }^{1)}$ Balai Riset dan Observasi Laut, Badan Riset Sumber Daya Manusia Kelautan dan Perikanan, \\ Kementerian Kelautan dan Perikanan \\ ${ }^{2}$ Loka Riset Perikanan Tuna, Badan Riset Sumber Daya Manusia Kelautan dan Perikanan, Kementerian \\ Kelautan dan Perikanan \\ ${ }^{3)}$ Balai Kawasan Konservasi Perairan Nasional, Direktorat Jenderal Pengelolaan Ruang Laut, \\ Kementerian Kelautan dan Perikanan \\ *e-mail: eghbert.ampou@kkp.go.id
}

\section{ABSTRACT \\ THE STATUS OF CORAL REEF DAN REEF FISH IN GILI MATRA, WEST NUSA TENGGARA}

This study aims to identify the status of reef fishes and coral reefs in Gili Meno, Air and Trawangan or Gili Matra waters. This area is part of the North Lombok Regency, West Nusa Tenggara Province. Field observation was conducted on September 2011 at 11 (eleven) diving points. The video-transect method was used for observing the coral reef condition, while reef fishes abundance was observed by using visual-census method. The parameter that used to determine the condition of coral reef in study location are the percentage of live hard coral cover and index of coral mortality. In general, the result shows that percentage of live hard coral cover in each diving point ranged from 4.4\% - 37.2\% and the Coral Mortality Index ranged from 0.400.92. The values describe that the condition of coral reef at eleven diving points vary from fair until poor condition. Current status of coral reef condition showed an unsignificant increase from good-very good to moderate during the period 1998 - 2018. There were 23 families of reef fishes from 46 genera were found during the study consisting of 16 genera of target fish groups, 5 genera of indicator fish group and 25 genera of major fish group. The water quality is still within the limits of environmental quality standards.

Keywords: Coral reef; reef fish; Mortality Index; water quality; Gili Matra

\section{PENDAHULUAN}

Wilayah laut Indonesia termasuk dalam kawasan segi tiga karang atau Coral Triangle Center dengan keanekaragaman karang dan ikan karang yang sangat tinggi (Veron et al., 2009). Sayangnya, terumbu karang merupakan ekosistem yang sangat rentan terhadap kerusakan. Beberapa faktor yang dapat mengancam keberadaan ekosistem ini adalah sedimentasi, pencemaran dari limbah industri dan rumah tangga, kegiatan perikanan yang tidak ramah lingkungan (menggunakan bahan peledak dan racun), kegiatan wisata, dan juga faktor alam seperti peningkatan suhu permukaan air laut yang dapat menyebabkan pemutihan karang jika terjadi dalam waktu yang lama (Hoegh-Guldberg, 1999; Grimsditch dan Salm, 2006; Setiawan et al., 2017), bahkan beberapa diantaranya mengalami penyakit karang (Ampou, 2010; Ampou et al., 2020). Berbagai parameter dapat digunakan untuk mengetahui kondisi kesehatan terumbu karang di Indonesia, diantaranya persentase tutupan karang hidup dan Indeks Mortalitas Karang (IMK) (Madduppa dan Zamani, 2011). 
Secara global, kondisi terumbu karang di Indonesia sebagian besar mengalami penurunan. Dari total 1067 lokasi, 36.18\% (386 lokasi) dalam kategori jelek; 34.3\% (366 lokasi) dalam kategori cukup (termasuk daerah Lombok, NTB dan sekitarnya); $22.96 \%$ (245) pada kategori baik; dan sisanya (6.56\% atau 70 lokasi) dalam kategori sangat baik (Hadi et al, 2018). Tren kondisi tutupan karang hidup mengalami penurunan di beberapa wilayah yang diakibatkan oleh fenomena pemutihan karang massal yang terjadi pada akhir tahun 2015 dan 2016 (Hadi et al. 2017), bahkan sebagian mengalami kematian dampak dari fenomena El-Nino tersebut yang mengakibatkan turunnya muka air laut sehingga karang terdedah dalam rentang waktu yang cukup lama (Ampou et al. 2017; Tito et al. 2019).

Gili Matra, sebuah kawasan konservasi yang terletak di ujung Barat Laut pulau Lombok merupakan kawasan Konservasi Perairan Nasional dengan kategori Taman Wisata Perairan,. Kawasan yang mencakup luas wilayah \pm 2.954 hektar ini terdiri dari 3 pulau kecil (gili), yaitu Gili Meno, Gili Air, dan Gili Trawangan (Gili Matra). Gili Matra merupakan salah satu kawasan pariwisata bahari di pulau Lombok yang banyak dikunjungi oleh wisatawan lokal maupun mancanegara, terutama bagi peminat wisata selam (Dirjen KP3K, KKP. 2014). Ekosistem terumbu karang dan biota lainnya yang tumbuh dan hidup di ekosistem tersebut (terutama ikan-ikan karang) menjadi daya tarik utama para wisatawan yang berkunjung, sehingga status kondisinya perlu selalu mendapat perhatian. Penelitian ini bertujuan untuk memberikan informasi kondisi status terumbu karang dan ikan karang di perairan Gili Matra.

\section{METODOLOGI}

\subsection{Metode Pengambilan Data}

\subsubsection{Tutupan Karang}

Penelitian ini dilaksanakan di Kawasan Konservasi Perairan Nasional Gili Matra, yang berada di wilayah kelola Balai Kawasan Konservasi Perairan (BKKPN) Kupang. Secara administratif, wilayah ini merupakan bagian dari wilayah desa Gili Indah, Kecamatan Pemenang, Kabupaten Lombok Timur, Provinsi Nusa Tenggara Barat. Pengambilan data lapangan dilakukan pada bulan September 2011 di 11 (sebelas) titik penyelaman, yang tersebar di Gili Trawangan (4 titik: Shark Point, Shallow Turbo, Biorock, Manta point), Gili Meno (3 titik: Meno Wall, Bounty, Meno 1), dan Gili Air (4 titik: Air Wall, Hans Reef, Secret Reef, Front Point) (Gambar 1).

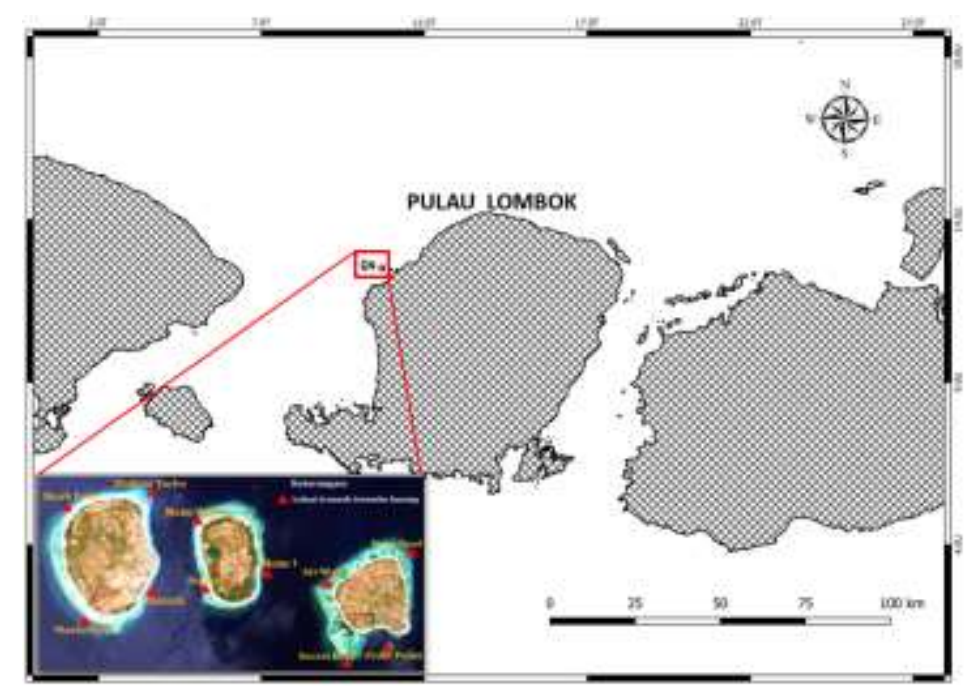

Gambar 1.Titik Pengambilan Data Terumbu Karang dan Ikan Karang di Gili Matra

Sumber: Peta Rupa Bumi Indonesia 2016 terbitan BIG \& Google Map 
Pengambilan data tutupan terumbu karang bertujuan untuk menghitung kelimpahan jenis karang keras (Dahl 1981; Clua et al., 2006). Metode yang digunakan untuk mengambil data tersebut adalah video transek sabuk (video-belt transect), modifikasi dari metode transek sabuk (belt transect). Pada metode ini digunakan kamera bawah air untuk merekam kondisi karang sepanjang transek dan luasan yang dilalui. Transek sepanjang 50 meter menjadi acuan, kemudian ditarik garis maya yang paralel dengan transek sepanjang 1 meter di kanan dan kiri transek sehingga membentuk luasan persegi panjang $2 \times 50 \mathrm{~m}^{2}$. Komponen penyusun dasar terumbu karang yang diamati digolongkan berdasarkan bentuk pertumbuhan. Pengamatan dilakukan satu kedalaman pada setiap lokasi yaitu di kedalaman 4 - 8 meter (English et al., 1997; Bianchi et al., 2004; Galparsoro et al., 2012).

\subsubsection{Ikan Karang}

Pengamatan ikan karang dilakukan dengan menggunakan metode visual census. Transek sepanjang 50m dibentangkan sejajar garis pantai dan mengikuti kontur dasar perairan. Pengamat ikan karang mengidentifikasi dan mencatat jenis dan jumlah ikan karang yang ditemukan di sekitar transek garis. Batas pengamatan atau pencatatan data ikan adalah 2.5 meter ke arah kiri dan ke kanan transek, sehingga luasan total pengamatan adalah $250 \mathrm{~m}^{2}$ (English et al., 1997; Bianchi et al. 2004).

Metode pengamatan terumbu karang dan ikan karang diilustrasikan pada Gambar 2.

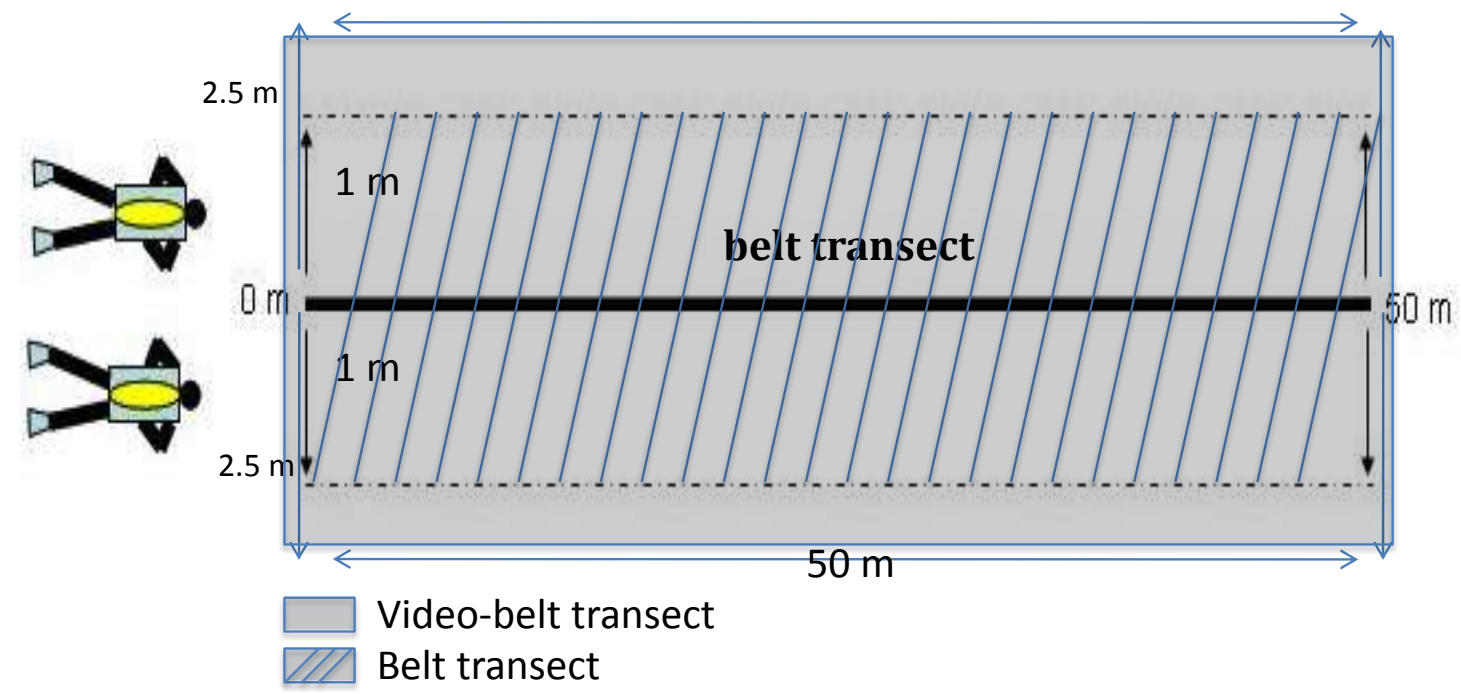

Gambar 2. Metode Video-Belt Transect dan Belt Transect yang Digunakan untuk Pengamatan Terumbu Karang dan Ikan Karang (English et al., 1997; Bianchi et al. 2004)

\subsubsection{Kualitas Air}

Pengukuran kualitas air dilakukan guna mengetahui kondisi perairan Gili Matra pada saat pengambilan data karang dan ikan karang. Sejumlah 28 titik ditentukan sebagai lokasi pengukuran kualitas air (Gambar 3). Parameter yang diukur meliputi suhu, oksigen terlarut, salinitas, dan $\mathrm{pH}$ (Tabel 1). 


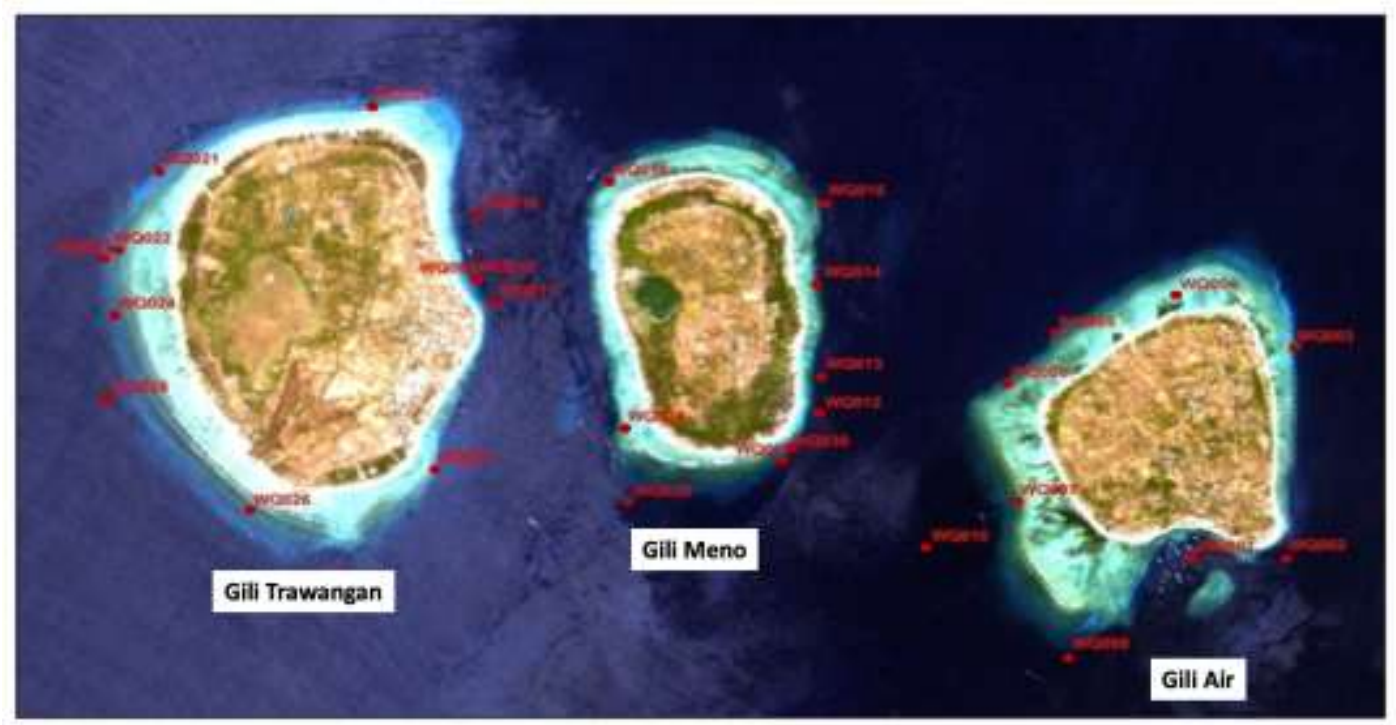

Gambar 3. Titik Pengukuran Parameter Kualitas Air di Perairan Gili Matra

Tabel 1. Parameter Kualitas Air dan Metode Pengambilan Data yang Digunakan

\begin{tabular}{|c|c|c|}
\hline Parameter & $\begin{array}{c}\text { Alat } \\
\text { Pengukur }\end{array}$ & Metode Pengukuran \\
\hline $\begin{array}{l}\text { Oksigen Terlarut (Dissolved Oxygen, } \\
\text { DO) }\end{array}$ & Titrasi & Pengukuran langsung di lapangan \\
\hline $\mathrm{pH}$ & pHmeter & \\
\hline Suhu $\left({ }^{\circ} \mathrm{C}\right)$ & Termometer & \\
\hline Salinitas (\%o) & Salinometer & \\
\hline
\end{tabular}

\subsection{Metode Analisis Data}

\subsubsection{Tutupan Karang}

Persentase tutupan karang dianalisis dengan mengidentifikasi dan mengklasifikasikan karang keras hidup (hard coral), karang mati (dead coral) dan jenis bentik lainnya, seperti pasir (sand); patahan karang (rubble); alga (turf algae); karang mati dengan alga (dead coral with algae); dan lainnya, yang berada dalam area transek $2 \mathrm{x}$ $50 \mathrm{~m}^{2}$. Penghitungan Indeks Mortalitas Karang (IMK) menggunakan rumus yang dikembangkan oleh Gomez dan Yap (1988), sebagai berikut:

$$
I M K=\frac{A}{(A+B)}
$$

Keterangan:

IMK = Indeks Mortalitas Karang (IMK)

$\mathrm{A}=$ Persentase tutupan karang mati (dead coral with algae + dead coral + rubble $)$
$\mathrm{B}=$ Persentase tutupan karang hidup (hard coral + soft coral)

\subsubsection{Ikan Karang}

Data hasil identifikasi ikan karang dianalisis dengan menghitung kelimpahan dan komposisinya. Kelimpahan jenis (ind $/ \mathrm{m}^{2}$ ) diketahui dengan membagi jumlah individu yang ditemukan di area pengamatan dengan luasan area yang diamati $\left(250 \mathrm{~m}^{2}\right)$. Sementara komposisi ikan karang diketahui dengan menghitung dan mengklasifikasikan ikan berdasarkan genus dan famili, lalu dikelompokan berdasarkan peranannya dalam ekosistem terumbu karang, yaitu ikan mayor, ikan target, dan ikan indikator (English et al., 1997; Bianchi et al. 2004).

Kelompok ikan indikator merupakan spesies ikan yang sangat tergantung dengan keberadaan karang di suatu perairan. 
Kelompok ikan target merupakan ikan karang yang hidup berasosiasi dengan ekosistem perairan karang, yang memiliki nilai ekonomis penting atau disebut juga ikan ekonomis. Sedangkan kelompok ikan mayor merupakan ikan yang tidak termasuk dalam kelompok ikan indikator dan ikan target, ikan ini biasanya dalam jumlah banyak dan dijadikan ikan hias air laut (Allen dan Steene, 1994; English et al., 1997).

\subsubsection{Kualitas Air}

Hasil pengukuran parameter kualitas air di dua puluh delapan titik yang tersebar di perairan Gili Matra lalu di hitung nilai ratarata, minimum, maksimum, dan kisarannya. Kondisi kualitas perairan diketahui dengan membandingkan nilai rata-rata hasil pengukuran di setiap titik tersebut dengan baku mutu kualitas air untuk kehidupan biota laut dan wisata bahari yang tertuang dalam Keputusan Menteri Lingkungan Hidup No. 51 Tahun 2004 tentang Baku Mutu Air Laut.

\section{HASIL DAN PEMBAHASAN}

\subsection{Gambaran Kondisi Lokasi Pengambilan Data}

Wilayah perairan Gili Matra ditetapkan sebagai kawasan konservasi karena memiliki keanekaragaman jenis biota laut. Letak Gili Matra secara berurutan dari pulau Utama Lombok ke arah selat Lombok adalah Gili Air, Gili Meno, lalu Gili Trawangan. Gili Air letaknya paling dekat dengan pulau Lombok, sehingga kondisinya banyak dipengaruhi oleh daratan. Sementara Gili Meno terletak di tengah-tengah, antara Gili Air dan Gili
Trawangan. Luas pulau ini adalah \pm 188 ha. Di bagian Barat Gili Meno terdapat danau air asin yang dikelilingi oleh vegetasi mangrove. Luas daratan Gili Meno \pm 150 ha. Gili Trawangan adalah gili yang paling jauh dari daratan Pulau Lombok dan memiliki daratan terluas dibandingkan Gili Meno dan Gili Air (Dirjen KP3K 2014).

\subsection{Kondisi Tutupan Karang}

Berdasarkan hasil pengamatan persentase karang hidup di kesebelas titik penyelaman diketahui bahwa kondisi terumbu karang di Gili Matra tidak ada yang dalam kategori baik. Titik Meno 1 mempunyai persentase penutupan karang keras (hard coral) yang paling tinggi dibdaningkan dengan titik pengambilan data lainnya (Gambar 4). Penutupan karang keras di lokasi tersebut mencapai $37.2 \%$ dan termasuk dalam kategori sedang. Karang keras yang dijumpai di lokasi ini sebanyak 10 jenis, yang terdiri dari Porites sp., Seriatopora sp., Acropora sp., Pocillopora sp., Fungia sp., Montipora sp., Stylophora sp., Hydnopora sp., Favites sp., dan Goniastrea sp. Selain karang keras, di lokasi ini juga ditemukan karang lunak (soft coral) dengan penutupan $16.4 \%$. Jenis-jenis yang ditemukan adalah Sinularia sp., Lobophytum sp., dan Nephtea sp. Penutupan karang mati beralga (dead coral with algae) sebesar 19.4\%; patahan karang (rubble) sebesar 21.4\%; turf algae sebesar $1.2 \%$; biota lain (other) sebesar 2.8\%; serta pasir (sand) $6.7 \%$. Indeks Mortalitas Karang (IMK) di lokasi ini tergolong sedang dengan nilai 0.52 . 


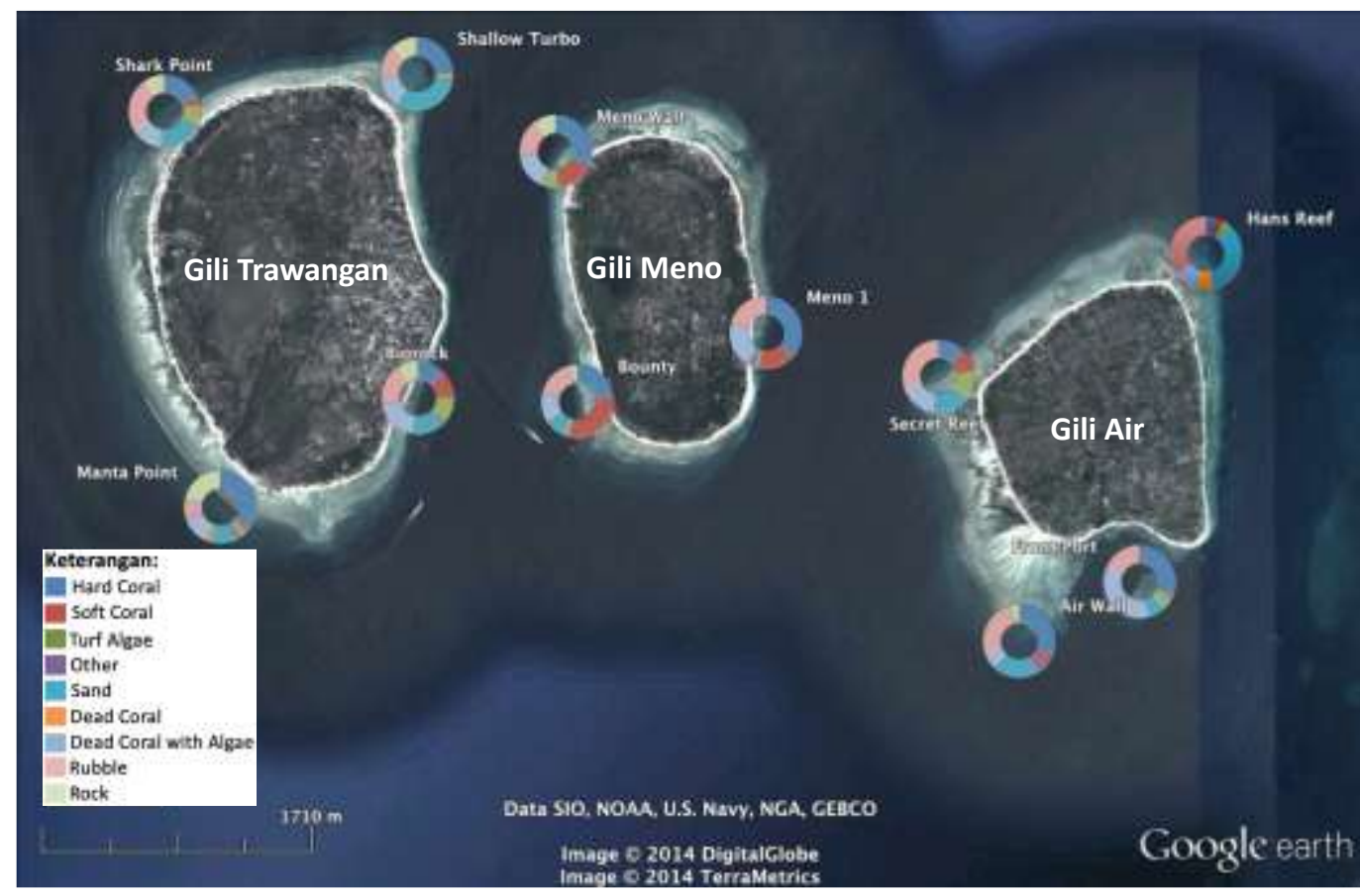

Gambar 4. Kondisi Tutupan Karang dan Benthic Lifeform di Lokasi Pengambilan Data di Perairan Gili Matra

Titik Hans Reef mempunyai persentase tutupan karang keras yang paling rendah (4.4\%) dibandingkan dengan lokasi pengambilan data lainnya. Hal ini menunjukan bahwa kondisi terumbu karang di lokasi tersebut dalam kriteria buruk/jelek. Di lokasi ini ditemukan 4 jenis karang keras, yaitu Porites sp., Seriatopora sp., Pocillopora sp., dan Acropora sp. Selain karang keras, di lokasi ini juga tercatat adanya karang lunak dengan tutupan sebesar $3.9 \%$. Jenis yang dijumpai meliputi Sinularia sp., Lobophytum sp., dan Nephtea sp. Selain itu, di lokasi ini juga terdapat tutupan koral mati beralga sebesar $11.2 \%$, karang mati sebesar $7.2 \%$, pecahan karang sebesar $34.9 \%$, turf algae sebesar 3\%, dan pasir sebesar 35.4\%. Pasir dan patahan karang (rubble) mendominasi lokasi ini, sehingga dijadikan sebagai lokasi pelatihan selam oleh para pemula, guna menghindari rusaknya karang hidup.

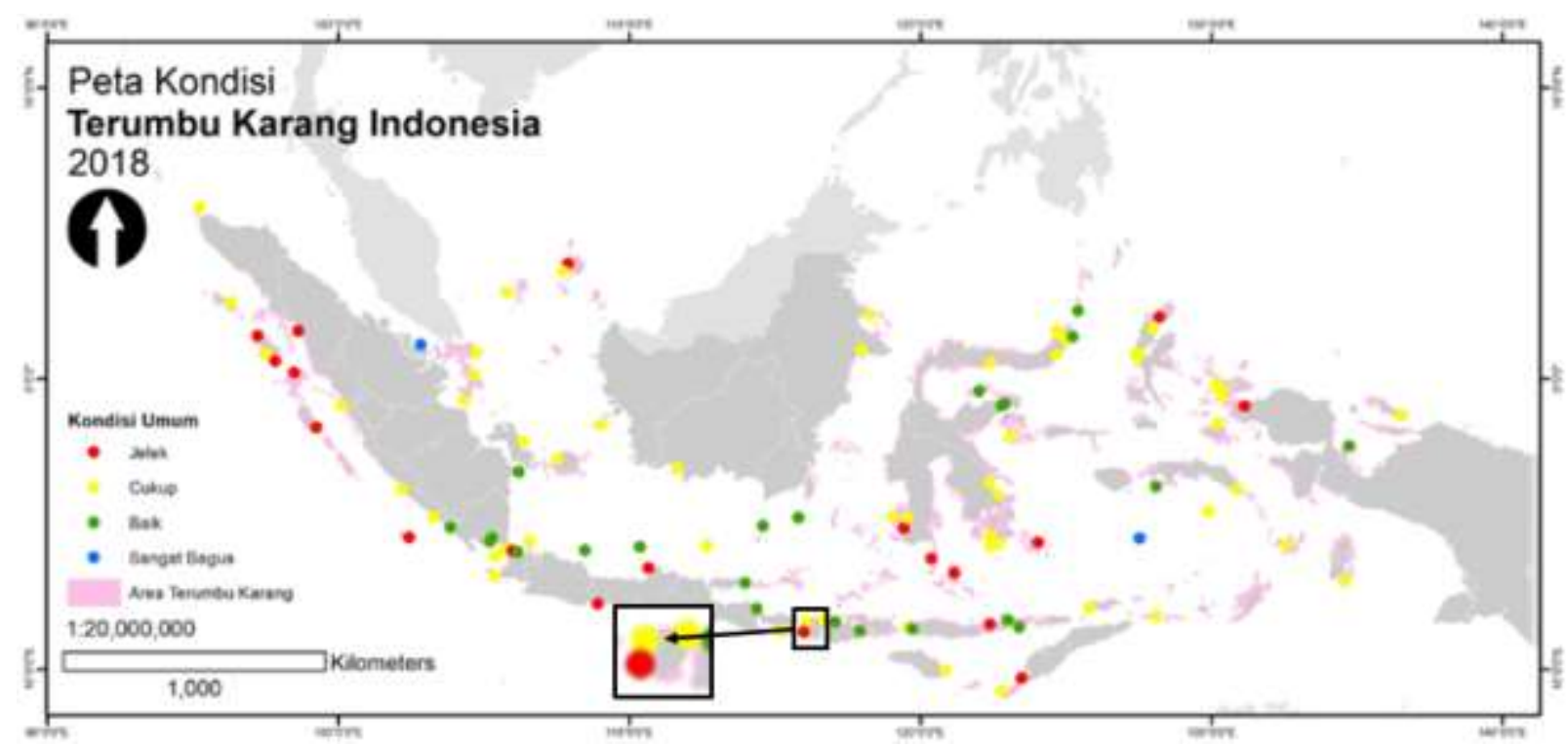

Gambar 5. Kondisi Status Terumbu Karang di Indonesia 2018, Kotak Hitam dengan Lingkaran Kuning Menunjukkan Lokasi Gili Matra (Hadi et al., 2018) 
Indeks Mortalitas Karang (IMK) di lokasi ini tergolong tinggi dengan nilai 0.92. Nilai IMK pada lokasi ini telah mendekati 1, yang menunjukkan bahwa terjadi perubahan yang berarti dari tutupan karang hidup menjadi karang mati. IMK di suatu lokasi menunjukkan tingkat kerusakan ekosistem terumbu karang terkait dengan besarnya perubahan karang hidup menjadi karang mati. IMK pada setiap lokasi pengamatan ditampilkan pada Tabel 3. Berdasarkan nilai indeks mortalitas masing-masing lokasi mempunyai tingkat kerusakan terumbu karang yang tinggi, yang masuk dalam kategori jelek. Hampir di setiap lokasi nilai IMK mendekati nilai 1. Menurut English et. al. (1997) kondisi terumbu karang dikatakan memiliki rasio kematian yang tinggi jika nilai IMK mendekati 1 . Hal ini diperkuat dengan tingkat penutupan substrat oleh karang mati beralga (death coral with algae, karang mati (death coral) dan pecahan karang (rubble) yang tinggi pada kedua titik pengamatan tersebut.

Status kondisi terumbu karang di Gili Matra mengalami perubahan dari tahun ke tahun (Tabel 2). Kondisi terumbu karang tahun 1998 dalam kondisi baik - sangat baik. Kemudian mengalami penurunan kualitas pada tahun 2000 hingga sebelum 2017. Di periode 2017-2018, kondisi membaik namun tidak terlalu signifikan, yaitu dari jelek/buruk ke cukup/sedang (Giyanto et al., 2017; Hadi et al., 2018). Klasifikasi habitat secara detail telah dilakukan menggunakan citra satelit beresolusi tinggi (world view 2) oleh Manessa et al. (2014). Sedangkan proses perubahan ekosistem terumbu karang secara signifikan akan sangat terlihat jelas jika menggunakan data citra satelit beresolusi sangat tinggi dan time series (Andréfouët et al., 2001; Scopélitis et al., 2009; Iovan et al., 2015; Ampou et al., 2018).

Proses pemulihan ekosistem terumbu karang sangat tergantung pada resistant, dimana kemampuan suatu ekosistem, dalam hal ini terumbu karang untuk tahan terhadap gangguan tanpa melalui fase pergeseran atau kehilangan struktur atau fungsi, contoh kemampuan terumbu karang untuk tahan terhadap pemutihan dan kematian (Odum, 1989; Grimsditch dan Salm, 2006). Dan resilient, kemampuan suatu sistem untuk menyerap atau pulih dari gangguan dan perubahan, sambil mempertahankan fungsi dan layanannya (Carpenter et al,. 2001; Grimsditch dan Salm, 2006).

Tabel 2. Beberapa Publikasi Perubahan Status Terumbu Karang di Gili Matra

\begin{tabular}{lcc}
\hline \multicolumn{1}{c}{ Referensi } & Tahun Pengambilan Data & Status \\
\hline Dahuri et al. (1998) & 1998 & Baik - Sangat Baik \\
BKSDA (2000) & 2000 & Jelek - Baik \\
Bachtiar (2004) & 2000 & Jelek - Sedang \\
Ahyadi (2010) & 2010 & Jelek - Sedang \\
Ampou et al (ulasan saat ini) & 2011 & Jelek \\
Suana \& Ahyadi (2012) & 2012 & Jelek \\
COREMAP-CTI, (2014) & 2014 & Jelek \\
Giyanto et al. (2017) & 2017 & Jelek - Cukup \\
Hadi et al. (2018) & 2018 & Cukup \\
\hline
\end{tabular}


Tabel 3. Indeks Mortalitas Karang (IMK) di Setiap Lokasi Pengambilan Data di Gili Matra

\begin{tabular}{lc}
\hline \multicolumn{1}{c}{ Lokasi } & $\begin{array}{c}\text { Indeks Mortalitas } \\
\text { Karang (IMK) }\end{array}$ \\
\hline Hans Reef & 0.92 \\
Secret Reef & 0.79 \\
Front Port & 0.63 \\
Air Wall & 0.51 \\
Meno 1 & 0.52 \\
Meno Wall & 0.51 \\
Manta Point & 0.40 \\
Shark Point & 0.67 \\
Shallow Turbo & 0.54 \\
Bounty & 0.58 \\
Biorock & 0.75 \\
\hline
\end{tabular}

\subsection{Ikan Karang}

Berdasarkan observasi dan identifikasi dalam penelitian ini, diperoleh data bahwa rata-rata kelimpahan ikan karang di Gili Matra secara kolektif adalah 5738 individu/ha. Kelimpahan ikan karang tertinggi dijumpai di lokasi Manta Point (Gili Trawangan), yaitu 7700 individu/ha; sedangkan kelimpahan terendah terdapat di Shallow Turbo (Gili Trawangan) dengan jumlah 3500 individu/ha (Gambar 6). Tarigan et al (2016) mencatat bahwa rata-rata kelimpahan ikan karang di Gili Matra telah mencapai 12.747 individu/ha dengan nilai tertinggi sebesar 22.936,67 individu/ha di lokasi Biorock dan terendah sebesar 7.910 individu/ha di lokasi Bongkas Reef. Jumlah tersebut menunjukan bahwa adanya peningkatan kelimpahan ikan karang di Gili Matra.

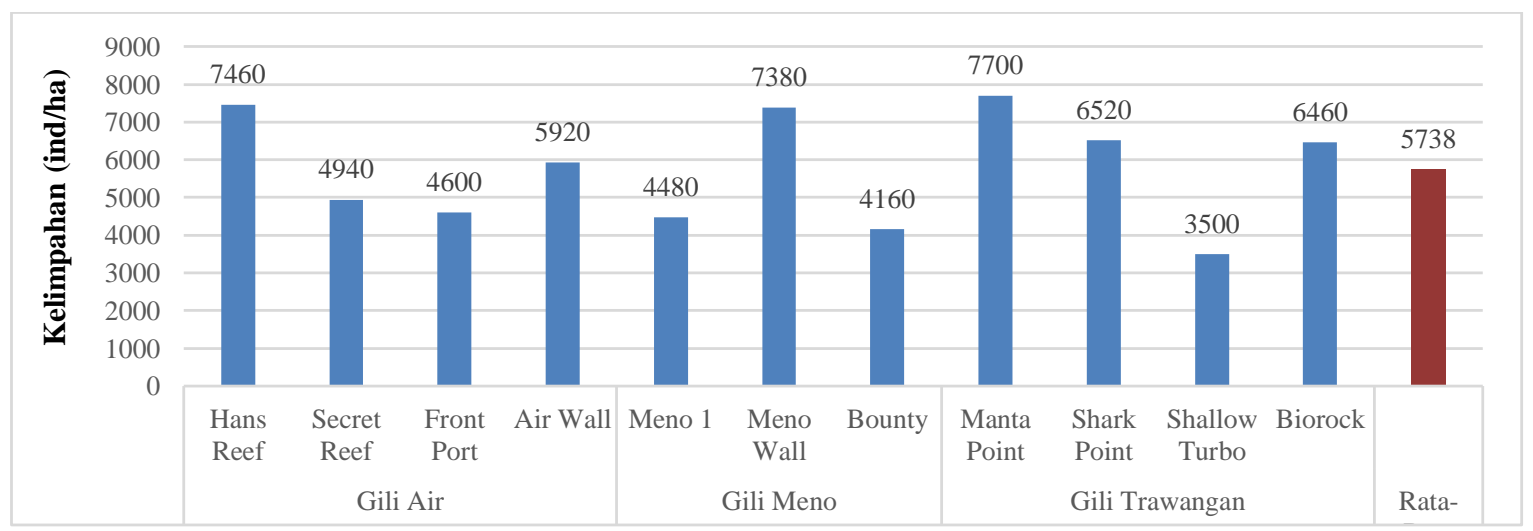

Gambar 6. Kelimpahan Ikan Karang di Lokasi Pengambilan Data di Gili Matra

Ikan karang yang tercatat pada survei ini (2011) termasuk kedalam 52 genera dari 23 famili. Pomacentridae adalah famili ikan karang yang paling banyak dijumpai $(59,79 \%)$, lalu diikuti dengan famili Balistidae $(10,49)$ dan Chaetodontidae $(6,69 \%)$ (Gambar 7). Jumlah tersebut lebih banyak dibandingkan dengan hasil survei sebelumnya yang menemukan ikan karang sebanyak 54 spesies dari 11 famili (Ahyadi, 2010). Pada tahun 2014, ikan karang di Gili Matra mengalami peningkatan dengan jumlah ditemukannya 111 spesies dari 17 famili (COREMAP-CTI, 2014). Kondisi ikan karang di Gili Matra mengalami peningkatan diversitas dan diharapkan dapat mendekati kondisi pada tahun 1998, yang berhasil mengidentifikasi ikan karang sebanyak 123 spesies dari 33 famili (Dahuri et al, 1998). Dengan adanya pertumbuhan populasi ikan, baik jenis atau biomasa, dapat mengindikasikan keberhasilan pengelolaan suatu kawasan konservasi perairan. Rehabilitasi ekosistem terumbu karang dan mekanisme kontrol dalam eksploitasi ikan karang sangat diperlukan untuk meningkatkan kondisi ekologis di perairan Gili Matra dari waktu ke waktu (COREMAP-CTI, 2014). 


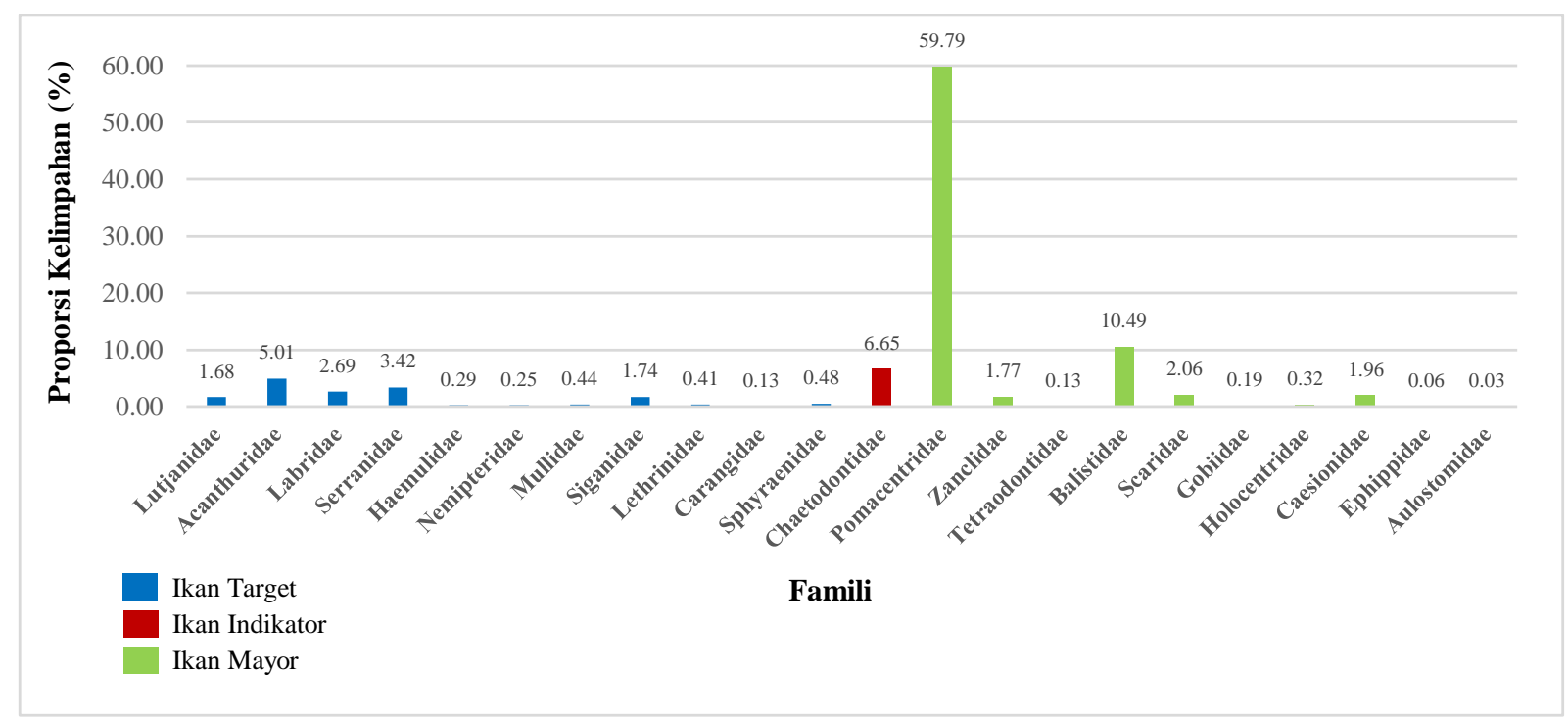

Gambar 7. Persentase Komposisi Ikan Karang di Lokasi Pengambilan Data di Gili Matra

Meskipun kondisi ekosistem terumbu karangnya tidak terlalu baik, namun berdasarkan peranannya ikan karang yang ditemukan di Gili Matra masih dalam kondisi lengkap, baik kelompok ikan target, ikan mayor, maupun ikan indikator. Hasil analisis menunjukan bahwa yang paling banyak ditemukan adalah ikan mayor $(76,81 \%)$, lalu berturut-turut ikan target $(16,54 \%)$ dan ikan indikator $(6,69 \%)$ (Gambar 8).

Menurut English et al (1997), ikan target merupakan ikan ekonomis penting dan biasa ditangkap untuk dikonsumsi. Kelompok ikan ini biasanya menjadikan terumbu karang sebagai tempat memijah, sarang, atau daerah asuhan. Sebanyak 16 genera ikan target dari 12 famili dapat dijumpai dalam penelitian ini. Kelimpahan ikan target tertinggi ada pada lokasi Bounty di Gili Meno (Gambar 88) dengan jumlah 2240 individu/ha. Pada tahun 2014, ditemukan lebih banyak ikan target, yaitu 84 spesies ikan target dari 16 famili (COREMAP-CTI, 2014). Sebagaimana tertera pada Gambar 77, ikan target yang dijumpai di Gili Matra diwakili oleh famili Lutjanidae (ikan kakap), Acanthuridae (ikan pakol), Labridae, Serranidae (ikan kerapu), Haemulidae (ikan bibir tebal), Nemipteridae (ikan kurisi), Mullidae (ikan kuniran), Siganidae (ikan baronang), Lethrinidae (ikan lencam), Carangidae (ikan selar), dan Sphyraenidae (ikan barakuda).
Ikan indikator adalah jenis ikan karang yang khas mendiami daerah terumbu karang dan menjadi indikator kesuburan ekosistem tersebut (English et al, 1997). Ikan jenis ini masih ditemukan di Gili Matra, meskipun hanya dalam jumlah yang sedikit $(6,65 \%$ dari 3156 individu/ha). Lokasi yang paling banyak ditemukan ikan indikator tersebut adalah Biorock di Gili Trawangan (Gambar 8). Menurut Edrus dan Suharti (2016) bahwa status jenis ikan karang di Gili Matra meningkat cukup signifikan, meskipun beberapa jenis ikan dari golongan herbivora belum bisa mendukung secara maksimal dalam proses daya lenting terumbu karang. COREMAP-CTI (2014) juga menemukan hal yang sama bahwa lokasi Biorock paling banyak ditemukan ikan indikator. Di lokasi ini terdapat terumbu karang buatan (biorock) yang selain berfungsi untuk mempercepat pertumbuhan karang juga digunakan sebagai tempat berlindung ikan. Ikan indikator yang dijumpai tersebut diwakili oleh famili Chaetodontidae (ikan kepe-kepe), terdiri dari 5 genera. Nash (1998) menguraikan juga bahwa keberadaan ikan indikator ini menjadi salah satu indikasi kesehatan ekosistem terumbu karang di suatu wilayah. Suatu ekosistem terumbu karang dianggap sehat atau dalam kondisi baik jika dapat ditemukan setidaknya 44 spesies ikan indikator, seperti yang ditemukan di perairan Papua. 


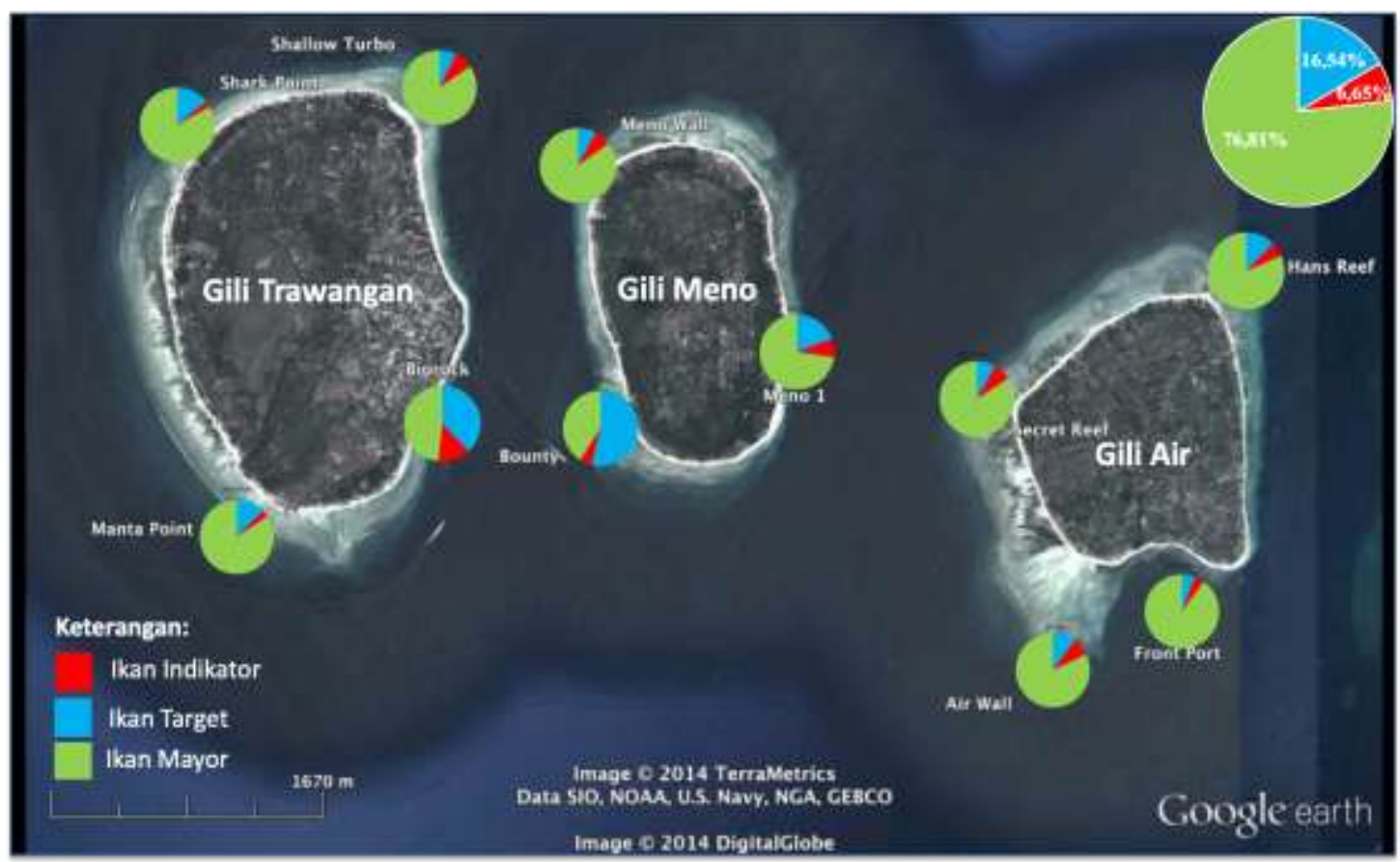

Gambar 8. Distribusi Spasial Kelimpahan Ikan Target, Ikan Mayor, Ikan Indikator di Perairan Gili Matra

Di Gili Matra, ditemukan sebanyak 25 genera ikan mayor dari 10 famili, yaitu famili, Pomacentridae, Zanclidae, Tetraodontidae, Balistidae, Scaridae, Gobiidae, Holocentridae, Caesionidae, Ephippidae, dan Aulostomidae. Pomacentridae adalah famili yang paling banyak ditemukan (Gambar 77). Ikan mayor ditemukan dengan proporsi kelimpahan $>50 \%$ di hampir semua lokasi pengamatan di ketiga gili (Gambar 88). Kelompok ikan ini biasanya ditemukan dalam jumlah yang melimpah, berukuran kecil (5$25 \mathrm{~cm}$ ), dengan karakteristik perwarnaan yang beragam sehingga biasanya dikenal sebagai ikan hias (English et al, 1997).

\subsection{Kualitas Air}

Hasil pengukuran kualitas air di 28 titik (Gambar 3) menunjukan bahwa kondisi kualitas perairan di Gili Matra pada saat pengambilan data masih berada di bawah baku mutu air laut, baik untuk kehidupan biota laut dan wisata bahari (Tabel 4). Parameter kualitas air yang membatasi kehidupan terumbu karang yang diukur dalam penelitian ini adalah suhu, salinitas, $\mathrm{pH}$, dan oksigen terlarut (DO). Akan tetapi, kondisi ini belum dapat menggambarkan kondisi kualitas perairan Gili Matra secara umum. Pengukuran hanya dilakukan satu kali, sehingga hanya menggambarkan kondisi perairan pada saat survei dilakukan.

Tabel 4. Hasil Pengukuran Kualitas Air di Gili Matra pada Saat Survei Lapangan (BPOL, 2011)

\begin{tabular}{lccccc}
\hline \multirow{2}{*}{ Parameter } & \multirow{2}{*}{ Rata-rata } & \multirow{2}{*}{ Minimum } & \multirow{2}{*}{ Maksimum } & \multicolumn{2}{c}{ Baku Mutu* } \\
\cline { 5 - 6 } Suhu $\left({ }^{\circ} \mathrm{C}\right)$ & $26.8^{\circ} \mathrm{C}$ & $24.1^{\circ} \mathrm{C}$ & $29.1{ }^{\circ} \mathrm{C}$ & $28-30{ }^{\circ} \mathrm{C}$ & Niota \\
DO & $4.7 \mathrm{mg} / \mathrm{l}$ & $4.31 \mathrm{mg} / 1$ & $5.33 \mathrm{mg} / \mathrm{l}$ & $>5 \mathrm{mg} / \mathrm{l}$ & $>5 \mathrm{mg} / \mathrm{l}$ \\
Salinitas (\%) & 34.7 & 33 & 35 & $33-34$ & Natural \\
$\mathrm{pH}$ & 7.9 & 7.3 & 8.2 & $7-8.5$ & $7-8.5$ \\
\hline
\end{tabular}

*Menurut Keputusan Menteri Lingkungan Hidup No. 51 Tahun 2004 tentang baku mutu air laut 


\section{SIMPULAN DAN SARAN}

\subsection{Simpulan}

1. Secara umum, kondisi tutupan karang di Gili Matra bervariasi dalam kondisi sedang sampai jelek/buruk, dimana kondisi terbaik ditemukan di Gili Meno. Kondisi terumbu karang di Gili Matra mengalami perubahan dari tahun ke tahun. Kondisi baik - sangat baik di tahun 1998, dan mengalami penurunan pada dekade 2000 hingga periode sebelum 2017. Tahun 2017-2018, kondisi membaik namun tidak terlalu signifikan, yaitu dari jelek/buruk ke cukup/sedang.

2. Populasi ikan karang di wilayah studi masih dalam komposisi lengkap, masih ditemukan ikan kelompok indikator, target, dan mayor. Namun, jumlah kelompok ikan indikator sebagai indikator kesehatan karang ditemukan dalam jumlah yang relatif sedikit.

3. Kondisi kualitas air pada saat survei penelitian ini dalam kategori baik karena masih di bawah baku mutu yang ditetapkan.

\subsection{Saran}

1. Perlu dilakukan monitoring lanjutan terkait status ekosistem terumbu karang di Gili Matra secara spasial/citra beresolusi sangat tinggi dan perubahan habitatnya apakah resistant atau resilient.

2. Perlu adanya kebijakan zonasi dalam proses eksploitasi ikan karang di Gili Matra.

3. Pengukuran kualitas air laut secara periodik untuk mendapatkan gambaran fluktuasi kondisi perairan di Gili Matra.

\section{UCAPAN TERIMA KASIH}

Penulis mengucapkan terima kasih kepada Balai Penelitian dan Observasi Laut, Kementerian Kelautan dan Perikanan (sekarang Balai Riset dan Observasi Laut) atas dukungan dana DIPA 2011, tim dari Fakultas Biologi Universitas Mataram dan dive center lokal dalam proses pengambilan data di lapangan, serta kepada semua pihak yang membantu kelancaran penelitian ini.

\section{DAFTAR PUSTAKA}

Allen, G. R., dan Steene, R. 1994. IndoPacific Coral Reef Field Guide. Tropical Reef Research 378pp.

Ahyadi, H. 2010. Evaluasi sumber daya terumbu karang untuk wisata di Gili Trawangan Propinsi Nusa Tenggara Barat. Desertasi Pascasarjana. Institut Pertanian Bogor, Bogor.

Ampou, E.E. 2010. Study of Prevalence on Coral Bleaching and Diseases. Jurnal Ilmu Lingkungan (Journal of Environmental Science). v. 5, n. 2, p. 123 - 128, ISSN 1907-5626. https://ojs.unud.ac.id/index.php/ECOT $\underline{\text { ROPHIC/article/view/13597 }}$

Ampou, E.E., Johan, O., Menkes, C.E., Niño, F., Birol, F., Ouillon, S., Andréfouët, S. 2017. "Coral Mortality Induced by the 2015-2016 El-Niño in Indonesia: The Effect of Rapid Sea Level Fall." Biogeosciences 14 (4): 817-26. https://doi.org/10.5194/bg-14-8172017.

Ampou, E.E., Ouillon, S., Iovan, C., Andréfouët, S. 2018. "Change Detection of Bunaken Island Coral Reefs Using 15 Years of Very High Resolution Satellite Images: A Kaleidoscope of Habitat Trajectories." Marine Pollution Bulletin 131 (June): 83-95.

https://doi.org/10.1016/j.marpolbul.20 17.10.067.

Ampou, E.E., Triyulianty, I., Widagti, N., Nugroho, S.C., Pancawati, Y. 2020. "Bakteri Pada Karang Scleractinia di Kawasan Perairan Bunaken, Morotai dan Raja Ampat". Jurnal Pesisir dan Laut Tropis. Vol. 8, No. 1, Hal. 122134 , https://doi.org/10.35800/jplt.8.1.2020. $\underline{28128 .}$. 
Andréfouët, S, Muller-Karger, F. E., Hochberg, E. J., Hu, C., Carder, K. L. 2001. "Change Detection in Shallow Coral Reef Environments Using Landsat 7 ETM+ Data." Remote Sensing of Environment 78 (January): 150-62.

[BKSDA] Balai Konservasi Sumber Daya Alam. 2000. Laporan pendataan kondisi terumbu karang di Taman Wisata Alam Laut Gili Indah Propinsi Nusa Tenggara Barat, Mataram. p. 36.

[BPOL] Balai Penelitian dan Observasi Laut. 2011. Laporan Hasil Penelitian "Observasi dan Kajian Kawasan Konservasi Laut". BPOL, Kementerian Kelautan dan Perikanan.

Bachtiar, I. 2004. Status terumbu karang di Propinsi Nusa Tenggara Barat. Jurnal Biologi Tropis, 5(1), 1-9.

Bianchi, C. N., Pronzato, R., Cattaneo-Vietti, R., Benedetti Cecchi, L., Morri, C., Pansini, P., Chemello, R., Milazzo, M., Faschetti, S.,Terlizzi, A., Peirano, A., Salvati, E., Benzoni, F., Calcinai, B., Cerrano, C., Bavestrello, G. 2004. "Hard Bottoms." Biol. Mar. Medit. 11: 185-215.

Carpenter, S., Walker, B., Daneries, J.M., Abel, N. 2001. "From Metaphor to Measurement: Resilience of What to What?" Ecosystems, 2001. edsjsr.

Clua, E., Legendre, P., Vigliola, L., Magron, F., Kulbicki, M., Sarramegna, S., Labrosse, P., Galzin, R. 2006. "Medium Scale Approach (MSA) for Improved Assessment of Coral Reef Fish Habitat." Journal of Experimental Marine Biology dan Ecology $333 \quad$ (2): 219-30. https://doi.org/10.1016/j.jembe.2005.1 2.010 .

[COREMAP-CTI] Coral Reef Rehabilitation dan Management - Coral Triangle Initiative. 2014. Baseline survey kesehatan terumbu karang dan ekosistem terkait di Taman Wisata Perairan Gili Matram (p. 80).
COREMAP CTI Pusat Penelitian Oseanografi-LIPI. Jakarta.

Dahl, A. L. 1981. Coral Reef Monitoring Hdanbook. South Pacific Commission Noumea, New Caledonia.

Dahuri, R., Nikijuluw, V., Suparman, A., Yulidana, F., Setyobudi, I., Kinseng, R.A. 1998. Buku 1: Rencana pengelolaan taman wisata alam laut gili indah Propinsi Nusa Tenggara Barat. Proyek Penyusunan Neraca Sumber Daya Kelautan dan Pesisir Daerah. Kerjasama Dirjen Pembangunan Daerah dengan Dirjen Perlindungan Hutan dan Pelestarian Alam. Mataram.

Dirjen KP3K, KKP. 2014. "Master Plan Delta Api Desa Gili Indah - Kecamatan Pemenang, Kabupaten Lombok Utara. Konsep Pembangunan Desa Medana 2013 - 2023". Direktorat Jenderal Pesisir dan Pulau-Pulau Kecil, Kementrian Kelautan Perikanan. Santiri Foundation.

English, S., Wilkinson, C., Baker, V. 1997. Survey Manual for Tropical Marine Resources. 2nd edition., ASEAN. Townsville, Australia: Australia Marine Science Project, Living Coastal Resources, Australian Institute of Marine Science.

Edrus, I.N dan Suharti, S.R. 2016. Sumber Daya Ikan Karang di Taman Wisata Alam Gili Matra, Lombok Barat. Jurnal Penelitian Perikanan Indonesia, Vol. 22 No. 4, p-ISSN: 0853-5884, eISSN: 2502-6542, hal. 225-242.

Galparsoro, I., Connor, D.W., Borja, A., Aish, A., Amorim, P., Bajjouk, T., Chambers, C et al. 2012. "Using EUNIS Habitat Classification for Benthic Mapping in European Seas: Present Concerns dan Future Needs." Marine Pollution Bulletin 64 (12): 2630-38. https://doi.org/10.1016/j.marpolbul.20 $\underline{12.10 .010}$. 
Grimsditch, G.D dan Salm, R.V. 2006. "Coral Reef Resilience and Resistance to Bleaching." IUCN, Gland, Switzerland, 52pp.

Gomez, E.D dan Yap, H.T. 1988. Monitoring Reef Condition In Kenchington RA and Hudson B E T (ed). Coral Reef Management Hand Book. UNESCO. Regional Office for Science and Technology for South East Asia Jakarta.

Giyanto, Abrar, M., Hadi, T.A., Budiyanto, A., Hafizt, M., Salatalohy, A., Iswari, Y.M. 2017. Status Terumbu Karang Indonesia 2017. Jakarta: Pusat Penelitian Oseanografi - Lembaga Ilmu Pengetahuan Indonesia.

Hadi, T.A., Giyanto, G., Prayudha, B., Hafizt, M., Budiyanto, A., Suharsono. 2018. Status Terumbu Karang Tahun 2018. Jakarta: Pusat Penelitian Oseanografi - Lembaga Ilmu Pengetahuan Indonesia.

Hoegh-Guldberg, O. 1999. Climate change, coral bleaching and the future of the world's coral reefs. Journal Marine and Freshwater Research. Vol. 50, 8 : 839-866.

Iovan, C., Ampou, E., Andréfouët, S., Ouillon, S., Gaspar, P. 2015. "Change Detection of Coral Reef Habitats from Multi-temporal and Multi-source Satellite Imagery in Bunaken, Indonesia". $8^{\text {th }}$ International Workshop on the Analysis of Multitemporal Remote Sensing Images, 22-24 July 2015, Annecy, France. Publisher: IEEE-Institute of Electrical dan Electronics Engineers. DOI: 10.1109/Multi-Temp.2015.7245758.

Kepmen LH Nomor 51 Tahun 2004 Tentang "Baku Mutu Air Laut Untuk Biota Laut". Menteri Negara Lingkungan Hidup.

Manessa, M., Kanno, A., Sekine, M., Ampou, E.E., Widagti, $\mathrm{N}$ dan As-syakur, A.R. 2014. "Shallow-Water Benthic Identification Using Multispectral Satellite Imagery: Investigation on the
Effects of Improving Noise Correction Method dan Spectral Cover." Remote Sensing 6 (5): 4454-72. https://doi.org/10.3390/rs6054454.

Nash, S.V. 1988. Reef Diversity Index Survey Method for Non Sspecialist. Tropical Coastal Area Management. Vol. 4 (3): 14-17

Setiawan, F., Muttaqin, A., Tarigan S.A. 2017. Dampak Pemutihan Karang Tahun 2016 Terhadap Ekosistem Terumbu Karang: Studi Kasus Di TWP Gili Matra (Gili Air, Gili Meno dan Gili Trawangan) Provinsi NTB. Jurnal Kelautan: 10(2)

Madduppa, H dan Zamani, N.P. 2011. A Standard Criteria for Assessing the Health of Coral Reefs: Implication for Management and Conservation. Journal of Indonesia Coral Reefs 1(2) (2011) 137-146

Odum, P. O. 1989. Ecology dan Our Endangered Life-Support Systems. Sinauer Associates Inc: Sunderland (USA).

Scopélitis, J., Andréfouët, S., Phinn, S., Chabanet, P., Naim, O., Tourrdan, O., Done, T. 2009. "Changes of Coral Communities over 35 Years: Integrating in Situ dan RemoteSensing Data on Saint-Leu Reef (La Réunion, Indian Ocean)." Estuarine, Coastal and Shelf Science 84: 342-52.

Tarigan, S.A.R., Setiawan, F., Muttaqin, A., Muhidin, S.P., Hotmariyah., Sabil, A. 2017. Laporan Teknis: Monitoring Ekosistem Terumbu Karang Taman Wisata Perairan Tahun 2016. Wildlife Conservation Society. Bogor. Indonesia.

Tito, C.K., Ampou, E.E., Wibawa, T.A. 2019. "Stressor-Response of Reef-Building Corals to Climate Change in the Menjangan Island, West Bali National Park, Indonesia". IOP Conference Series: Earth and Environmental Science, Vol. 246. 4th International Conference on Tropical dan Coastal Region Eco Development 30-31 
October 2018, Semarang, Indonesia. https://iopscience.iop.org/article/10.10 88/1755-1315/246/1/012011.

Veron, J.E.N., Devantier, L.M., Turak, E., Green, A.L., Kininmonth, S., Stafford-
Smith, M., Peterson, N. 2009. Delineating the Coral Triangle. Galaxea, Journal of Coral Reef Studies 11: 91-100 